\title{
Activation of AMP-Activated Protein Kinase Prevents TGF- $\beta 1$-Induced Epithelial-Mesenchymal Transition and Myofibroblast Activation
}

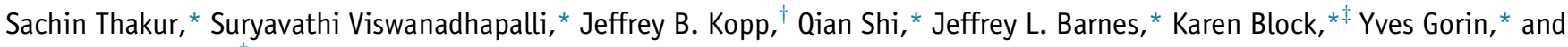
Hanna E. Abboud**

From the Department of Medicine, * University of Texas Health Science Center, San Antonio, Texas; the Kidney Disease Section, ${ }^{\dagger}$ Kidney Diseases Branch, National Institute of Diabetes and Digestive and Kidney Diseases, National Institutes of Health, Bethesda, Maryland; and the Audie L. Murphy Memorial Hospital Division, ${ }^{\ddagger}$ South Texas Veterans Healthcare System, San Antonio, Texas

\author{
Accepted for publication \\ April 21, 2015. \\ Address correspondence to \\ Suryavathi Viswanadhapalli, \\ Ph.D., Division of Nephrology, \\ Department of Medicine, The \\ University of Texas Health \\ Science Center, MC 7882, 7703 \\ Floyd Curl Dr., San Antonio, \\ TX 78229-3900. E-mail: \\ viswanadhapa@uthscsa.edu.
}

\begin{abstract}
Transforming growth factor (TGF)- $\beta$ contributes to tubulointerstitial fibrosis. We investigated the mechanism by which TGF- $\beta$ exerts its profibrotic effects and specifically the role of AMP-activated protein kinase (AMPK) in kidney tubular epithelial cells and interstitial fibroblasts. In proximal tubular epithelial cells, TGF- $\beta 1$ treatment causes a decrease in AMPK phosphorylation and activation together with increased fibronectin and $\alpha$-smooth muscle actin expression and decreased in E-cadherin. TGF- $\beta 1$ causes similar changes in interstitial fibroblasts. Activation of AMPK with 5-aminoimidazole-4-carboxamide 1- $\beta$-D-ribofuranoside, metformin, or overexpression of constitutively active AMPK markedly attenuated TGF- $\beta 1$ functions. Conversely, inhibition of AMPK with adenine 9- $\beta$-D-arabinofuranoside or siRNA-mediated knockdown of AMPK (official name PRKAA1) mimicked the effect of TGF- $\beta 1$ and enhanced basal and TGF- $\beta 1$-induced phenotypic changes. Importantly, we found that tuberin contributed to the protective effects of AMPK and that TGF- $\beta 1$ promoted cell injury by blocking AMPK-mediated tuberin phosphorylation and activation. In the kidney cortex of TGF- $\beta$ transgenic mice, the significant decrease in AMPK phosphorylation and tuberin phosphorylation on its AMPK-dependent activating site was associated with an increase in mesenchymal markers and a decrease in E-cadherin. Collectively, the data indicate that TGF- $\beta$ exerts its profibrotic action in vitro and in vivo via inactivation of AMPK. AMPK and tuberin activation prevent tubulointerstitial injury induced by TGF- $\beta$. Activators of AMPK provide potential therapeutic strategy to prevent kidney fibrosis and progressive kidney disease. (Am J Pathol 2015, 185: 2168-2180; http://dx.doi.org/10.1016/j.ajpath.2015.04.014)
\end{abstract}

Tubulointerstitial fibrosis is a prominent pathologic feature of progressive renal disease that culminates in loss of renal function. Inflammatory and metabolic insults result in kidney fibrosis in which transforming growth factor (TGF)- $\beta$ plays a prominent role. Tubular epithelial cells and interstitial fibroblast contribute to this process by secreting and remodeling the extracellular matrix. In progressive fibrotic renal disease, TGF- $\beta$ causes proximal tubular epithelial cells (PTECs) to acquire mesenchymal cell characteristics sometimes referred to as epithelialmesenchymal transition (EMT). ${ }^{1}$ In the presence of TGF- $\beta$, interstitial fibroblasts are also activated, differentiate to myofibroblasts, and contribute to the accumulation of extracellular matrix proteins. Accumulation of matrix proteins progressively destroys the normal kidney tissue architecture and disrupts blood flow and nephron function. ${ }^{2}$ The increase in TGF- $\beta 1$ levels is causally linked to the activation of profibrotic signaling

Supported by Merit Review grant 1I01BX001815-01A1 from the Veterans Administration (H.E.A. and J.L.B.), NIH grants RO-1 DK033665 (H.E.A., K.B., and Y.G.) and RO1 DK 079996 (Y.G.), and the NIH/National Institute of Diabetes and Digestive and Kidney Diseases Intramural Research Program (J.B.K.). Q.S. is supported by a fellowship grant from the Juvenile Diabetes Research Foundation.

S.T. and S.V. contributed equally to this work as senior authors.

The author H.E.A. is deceased.

This paper is dedicated to the memory of our wonderful friend and colleague Dr. Hanna E. Abboud, who recently passed away.

Portions of this work were presented in abstract form at Experimental Biology 2013 held 20-24 April, 2013, in Boston, MA.

Disclosures: None declared. 
pathways initiated by angiotensin, glucose, and oxidative stress. $^{3}$ There is substantial evidence supporting a role for AMPactivated protein kinase (AMPK) in multiple diseases, including diabetes mellitus, ${ }^{4,5}$ metabolic syndrome, ${ }^{6-9}$ and cancer. ${ }^{10,11}$ However, the role of AMPK in renal disease is underexplored. AMPK is a phylogenetically conserved serine/threonine kinase that regulates diverse cellular functions. ${ }^{12}$ AMPK is heterotrimeric complex comprising a catalytic $\alpha(\alpha 1, \alpha 2)$ subunit and two regulatory subunits $\beta(\beta 1, \beta 2)$ and $\gamma(\gamma 1, \gamma 2, \gamma 3)$. The activity and subunit composition of AMPK are expressed in a celland tissue-specific manner, with the $\alpha_{1}$ and $\alpha_{2}$ subunits expressed in the kidney, including tubular epithelial cells and glomerular cells. ${ }^{13,14}$ AMPK activation leads to its phosphorylation at Thr172 in the catalytic domain of the $\alpha$-subunit. AMPK can also be activated independent of changes in the AMP/ATP ratio. ${ }^{15-17}$ On activation, AMPK turns on ATP-generating catabolic pathways and turns off ATP-consuming anabolic pathways.

We investigated the role of AMPK in mediating the effect of TGF- $\beta 1$ in human and murine PTECs, rat kidney interstitial fibroblast cells, and TGF- $\beta 1$ transgenic mouse model. We provide strong evidence that TGF- $\beta$ induces EMT phenotype through inactivation of AMPK and that activation of AMPK prevents the effects of TGF- $\beta$.

\section{Materials and Methods}

\section{Reagents}

Cell culture reagents for primary human PTECs were purchased from Lonza (Walkersville, MD) and for murine PTECs and normal rat kidney interstitial fibroblasts, from Gibco (Grand Island, NY). Recombinant TGF- $\beta 1$ (240B) was purchased from R\&D Systems (Minneapolis, MN). 5-Aminoimidazole-4carboxamide 1- $\beta$-D-ribofuranoside (AICAR; A9978), adenine 9- $\beta$-D-arabinofuranoside (ARA; 5762), and metformin (D150959) were purchased from Sigma (St Louis, MO). Lipofectamine 2000 reagent (11668-019) was obtained from Invitrogen (Carlsbad, CA). Phospho-AMPK (Thr172) (2535), phospho-ACC (Ser79) (11818), AMPK $\alpha$ (2532), AMPK $\alpha 1$ (2795), AMPK $\alpha 2$ (2757), phospho-tuberin (Ser1387) (5584), and tuberin (3990) antibodies were purchased from Cell Signaling (Danvers, MA). Fibronectin (F3648), $\alpha$-smooth muscle actin ( $\alpha$-SMA) (A2547), and actin (A2066) antibodies were purchased from Sigma. AntiE-cadherin antibody (ab 53033) was purchased from Abcam (Cambridge, MA). Glyceraldehyde-3-phosphate dehydrogenase (GAPDH) (sc-25778), anti-rabbit IgG-HRP (sc-2004), and anti-mouse IgG-HRP (sc-2005) antibodies were obtained from Santa Cruz Biotechnology (Santa Cruz, CA).

\section{Cell Culture, Transfections, and Adenovirus Infection}

Primary human renal proximal tubular epithelial cells (HRPTECs) were purchased from Lonza. HRPTECs were grown in recommended renal epithelial cell growth medium supplemented with $0.5 \%$ fetal bovine serum (FBS), 10 $\mathrm{ng} / \mathrm{mL}$ of epidermal growth factor, $5 \mathrm{mg} / \mathrm{mL}$ of insulin, $0.5 \mathrm{mg} / \mathrm{mL}$ of hydrocortisone, $0.5 \mathrm{mg} / \mathrm{mL}$ of epinephrine, $6.5 \mathrm{mg} / \mathrm{mL}$ of triiodothyronine, $10 \mathrm{mg} / \mathrm{mL}$ of transferrin, 10 $\mathrm{mg} / \mathrm{mL}$ of gentamicin, and $50 \mathrm{ng} / \mathrm{mL}$ of amphotericin-B. HRPTECs were used between passages 2 and 6. SV-40 immortalized murine kidney proximal tubular epithelial (MCT) cells (kindly provided by Dr. Eric G. Neilson, Northwestern University, Evanston, IL) were grown in lowglucose Dulbecco's modified Eagle's medium containing $10 \%$ heat inactivated FBS, $100 \mathrm{U} / \mathrm{mL}$ of penicillin, and 100 $\mu \mathrm{g} / \mathrm{mL}$ of streptomycin. Normal rat kidney interstitial fibroblast cells (NRK-49F) were obtained from ATCC (Manassas, VA) grown in RPMI low-glucose medium supplemented with $10 \%$ FBS. All these cells were maintained in a humidified atmosphere containing $5 \% \mathrm{CO}_{2}$ at $37^{\circ} \mathrm{C}$. Confluent cells were growth arrested for 16 hours in serum-free medium before the experiment.

For the RNA interference experiments, siRNA duplexes specific for mouse and human AMPK $\alpha 1$, AMPK $\alpha 2$, and scrambled siRNA were purchased from Santa Cruz Biotechnology. Each siRNA is a pool of three target-specific siRNAs. Cells were transfected using lipofectamine 2000 (Invitrogen) according to the manufacturer's instructions. The siRNAs were used at concentration of $20 \mathrm{nmol} / \mathrm{L}$. Scrambled siRNAs (nontargeting siRNAs; $20 \mathrm{nmol} / \mathrm{L}$ ) served as controls to validate the specificity of the siRNAs. A replication-defective adenoviral vector encoding constitutively active AMPK (referred to as AdCA-AMPK) and dominant negative AMPK (referred to as AdDN-AMPK), a generous gift from Dr. Morris J. Birnbaum (University of Pennsylvania, Philadelphia, PA) was amplified in HEK293 cells. An adenovirus expressing green fluorescence protein (Ad-GFP) was used as control. Infection of cultured cells with AdCA-AMPK/AdDN-AMPK or Ad-GFP was performed at a multiplicity of infection of 50 for 24 hours. Wild-type active AMPK $\alpha 2$ (WT-AMPK $\alpha 2$ ) plasmid construct was procured from Addgene (Cambridge, MA). Cells were transfected with $1.0 \mu \mathrm{g}$ of WT-AMPK $\alpha 2$ or vector plasmid constructs using lipofectamine 2000.

\section{Alb/TGF- $\beta 1$ Transgenic Mice}

Kidney cortex was isolated from 16-week-old Alb/TGF- $\beta 1$ mice $(n=4)$ and wild-type mice $(n=3) .{ }^{18}$ These samples were used for immunohistochemistry (IHC), Western blotting, and mRNA analysis.

\section{Western Blot Analysis}

Cells were washed twice with ice-cold phosphate-buffered saline (PBS) and lyzed in ice-cold lysis buffer containing $20 \mathrm{mmol} / \mathrm{L}$ Tris- $\mathrm{HCl}$ (pH 7.5), $150 \mathrm{mmol} / \mathrm{L} \mathrm{NaCl}, 1 \mathrm{mmol} / \mathrm{L}$ $\mathrm{Na}_{2}$ EDTA, $1 \mathrm{mmol} / \mathrm{L}$ EGTA, $1 \%$ Triton, $2.5 \mathrm{mmol} / \mathrm{L}$ sodium pyrophosphate, $1 \mathrm{mmol} / \mathrm{L} \quad \beta$-glycerophosphate, $1 \mathrm{mmol} / \mathrm{L} \mathrm{Na}{ }_{3} \mathrm{VO}_{4}, 1 \mu \mathrm{g} / \mathrm{mL}$ of leupeptin, $1 \mathrm{mmol} / \mathrm{L}$ phenylmethylsulfonyl fluoride, and 1:100 dilution of phosphatase 
Table 1 Primer Sequences Used to Analyze mRNA Expression in Mouse Kidney Cortex and Normal Rat Kidney Interstitial Fibroblast Cells

\begin{tabular}{|c|c|c|}
\hline Gene & Forward primer & Reverse primer \\
\hline Rat Fn1 & $5^{\prime}-$ TGATTGGGAGGAAAAAGACAG-3' & 5'-CTGTGGAGGGAACATCCAA-3' \\
\hline Rat Acta2 & 5'-TGCCATGTATGTGGCTATTCA-3' & $5^{\prime}$-ACCAGTTGTACGTCCAGAAGC $-3^{\prime}$ \\
\hline Rat Gapdh & $5^{\prime}$-GCAAGAGAGAGGCCCTCAG-3' & 5'-TGTGAGGGAGATGCTCAGTG-3' \\
\hline Mouse Fn1 & 5'-TGCACGATGATATGGAGAGC-3' & 5'-TGGGTGTCACCTGACTGAAC-3' \\
\hline Mouse Acta2 & $5^{\prime}$-CCAGCACCATGAAGATCAAG- $3^{\prime}$ & $5^{\prime}$-TGGAAGGTAGACAGCGAAGC- $3^{\prime}$ \\
\hline Mouse Gapdh & 5'-AGGTCGGTGTGAACGGATTTG-3' & 5'-TGTAGACCATGTAGTTGAGGTCA-3' \\
\hline
\end{tabular}

inhibitor cocktails 1 and 2 (Sigma). Lysates were then centrifuged at $12,000 \times g$ for 20 minutes at $4^{\circ} \mathrm{C}$. Proteins were quantified. Equal amounts of proteins were separated by denaturing SDS-PAGE and transferred electrophoretically to polyvinylidene difluoride membranes (Millipore Corp., Bedford, MA). Membranes were incubated for 1 hour in $5 \%$ dry milk solution in tris-buffered saline with Tween 20 (TBST) $(20 \mathrm{mmol} / \mathrm{L}$ Tris-HCl, pH 7.5, $0.5 \mathrm{~mol} / \mathrm{L} \mathrm{NaCl}$, $0.5 \%$ Tween 20) for blocking. After washing thrice with TBST, membranes were incubated with primary antibody in $5 \%$ bovine serum albumin in TBST overnight at $4^{\circ} \mathrm{C}$. Membranes were washed three times in TBST followed by incubation with secondary antibody for 1 hour at room temperature and again washed three times at the end of incubation. Proteins were detected by incubating the polyvinylidene difluoride membrane with enhanced chemiluminescence reagents (Thermo Fisher, Rockford, IL) followed by exposing to X-ray film.

\section{Immunoprecipitation/Immunoblotting Studies}

Immunoprecipitation was performed using the Immunoprecipitation Kit (11719394001; Roche Life Science, Branford, CT). Protein extracts of HRPTECs treated with or without ARA and AICAR were incubated with a 1:100 dilution of AMPK $\alpha 1$ (2795), AMPK $\alpha 2$ (2757) antibody, or normal rabbit IgG (SC-2027) and gently rocked for 3 hours at $4^{\circ} \mathrm{C}$. A homogeneous protein-A agarose suspension was added to the mixture and incubated overnight at $4^{\circ} \mathrm{C}$ on a rocking platform. Immune complexes were collected by centrifugation at $12,000 \times g$ for 30 seconds in a microcentrifuge. After careful removal of supernatants, $1 \mathrm{~mL}$ of wash buffer $1(50 \mathrm{mmol} / \mathrm{L}$ Tris- $\mathrm{HCl}, 150 \mathrm{mmol} / \mathrm{L} \mathrm{NaCl}, 1 \% \mathrm{NP} 40,0.05 \%$ sodium deoxycholate) was added, and the beads were resuspended and incubated for 20 minutes at $4^{\circ} \mathrm{C}$ on a rocking platform. This washing process was repeated with wash buffers $2(50$ $\mathrm{mmol} / \mathrm{L}$ Tris- $\mathrm{HCl}, 500 \mathrm{mmol} / \mathrm{L} \mathrm{NaCl}, 0.1 \% \mathrm{NP} 40,0.05 \%$ sodium deoxycholate) and $3(10 \mathrm{mmol} / \mathrm{L}$ Tris- $\mathrm{HCl}, 0.1 \%$ NP40, $0.05 \%$ sodium deoxycholate), and complexes were collected and solubilized with $75 \mu \mathrm{L}$ of $2 \times$ Laemmli sample buffer. Proteins were denatured by heating to $100^{\circ} \mathrm{C}$ for 10 minutes; protein-A agarose was removed by centrifugation at $12,000 \times g$ for 60 seconds at room temperature in a microcentrifuge, and samples were analyzed by SDS-PAGE and Western blotting.
IHC

Paraffin slides were heated in a microwave in citrate buffer ( $\mathrm{pH}$ 6.0) for 6 minutes and quenched in 3\% hydrogen peroxide for 6 minutes and washed in TBS. Slides were then blocked with Sniper blocking buffer (Biocare, Concord, CA) for 20 minutes and incubated with fibronectin, $\alpha$-SMA, and E-cadherin antibodies overnight at $4^{\circ} \mathrm{C}$ in a humidified chamber. After rinsing, the slides were incubated with goat anti-rabbit polymer-horseradish peroxidase (HRP) (Biocare) for 20 minutes at room temperature. Immunoreactivity was visualized with diaminobenzidine (Biocare). Negative controls were performed by omitting the incubation with the primary antibody. Sections were photographed using Axio Imager.A1 microscope (Carl Zeiss, Melville, NY).

\section{Immunofluorescence}

PTECs and NRK-49F cells grown on 4-well chamber slides were fixed with $4 \%$ paraformaldehyde for 20 minutes. After PBS washing and permeabilization with $0.1 \%$ Triton-X 100 , the cells were then blocked with 5\% normal goat serum in PBS for 1 hour. Cells were washed with PBS and incubated with appropriate primary antibodies (fibronectin, $\alpha$-SMA, and E-cadherin) diluted in 1\% normal goat serum in PBS for 1 hour at room temperature. Cells were washed and then incubated with fluorescein isothiocyanate-conjugated antirabbit or Cyanin-3 anti-mouse antibodies as appropriate for 1 hour at room temperature. The cells were washed thrice with PBS, mounted, and counterstained using ProLong Gold antifade reagent having DAPI (Invitrogen) and visualized with Zeiss fluorescence microscope.

\section{RNA Extraction and Real-Time PCR}

RNA was extracted from HRPTECs and NRK-49F cells and the kidney cortex of Alb/TGF-b1 transgenic mice using Trizol (Invitrogen) and used for reverse transcription using iScript RT SuperMix (BioRad). The resulting cDNAs were used for quantitative PCR using the $\mathrm{RT}^{2}$ Real-Time Quantitative PCR Master Mix (BioRad). For HRPTECs, the following primers from SABiosciences/Qiagen (Valencia, CA) were used: fibronectin (FNl, http://www.ncbi.nlm.nih.gov/nuccore, accession number NM_002026.2; probe PPH00143B), $\alpha$-SMA (ACT2, accession number NM_001613.2; probe PPH01300B), 

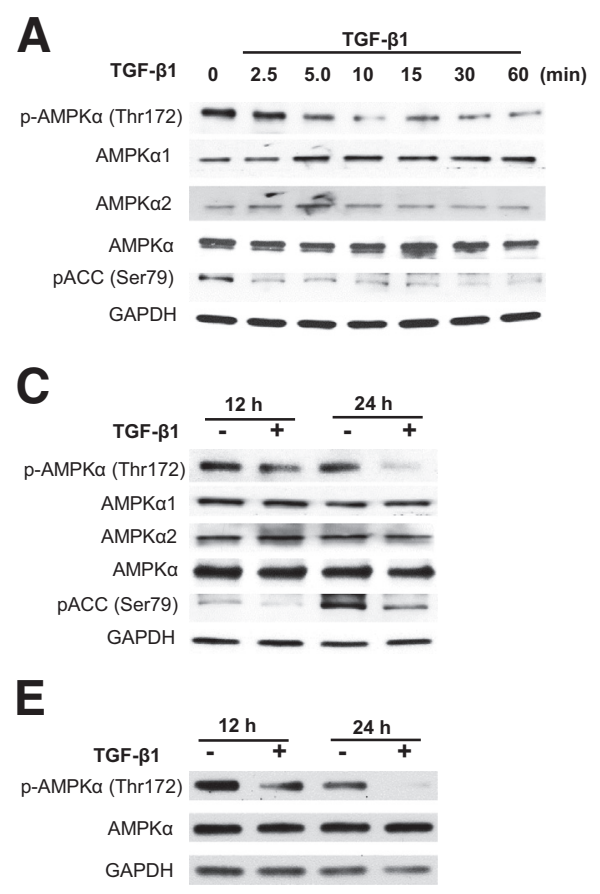

E-cadherin $(C D H 1$, accession number NM_004360.3; probe PPH00135F), and GAPDH (accession number NM_002046.3; probe PPH00150E). Primer sequences used to analyze mRNA expression of fibronectin, $\alpha$-SMA, and GAPDH for mouse kidney cortex and NRK-49F cells are given in Table 1 . The real-time quantitative PCR (qPCR) was run in a MasterCycler RealPlex4 (Eppendorf, Hamburg, Germany). Quantitation of the mRNAs was performed using the $2^{-\Delta \Delta \mathrm{Ct}}$ method using $G A P D H$ as a housekeeping gene. Duplicate experiments were performed, with three replicates. Results are expressed relative to control, which was arbitrarily assigned a value of 1 .

\section{Statistical Analysis}

Data were expressed as means \pm SEM and analyzed by analysis of variance for comparison among multiple groups using the Tukey posttest analysis for comparison using the GraphPad Prism software version 5.0 (GraphPad Software Inc, La Jolla, CA). $P<0.05$ was considered statistically significant.

\section{Results}

\section{TGF- $\beta 1$ Induces EMT via Inactivation of AMPK}

The role of AMPK in regulation of fibrogenic response induced by TGF- $\beta 1$ was examined in primary HRPTECs and immortalized MCT cells. HRPTECs were exposed to $1 \mathrm{ng} / \mathrm{mL}$ of TGF$\beta 1$ for a short duration starting from $0,2.5,5,10,15,30$, and 60 minutes and a long duration of 12 and 24 hours. Cell lysates were analyzed by SDS-PAGE and probed with phospho-AMPK (Thr172) or phospho-acetyl carboxylase coenzyme-A (pACC) (Ser79) antibodies. Figure 1A shows time-dependent inactivation of AMPK phosphorylation and also its downstream target pACC starting at 5 minutes. However, short incubation with
TGF- $\beta 1$ induced a time-dependent increase in the expression of fibronectin and $\alpha$-SMA (Figure 1B) but reduced the levels of E-cadherin in HRPTECs (Figure 1B). Prolonged treatment of the PTECs with TGF- $\beta 1$ markedly decreased phosphorylation of AMPK and pACC (Ser79) at 12 hours and 24 hours (Figure 1, $\mathrm{C}$ and $\mathrm{E}$ ). There was a robust increase in fibronectin expression with prolonged exposure to TGF- $\beta 1$ in PTECs (Figure 1, D and F). In addition to increased fibronectin, TGF- $\beta 1$ also increased $\alpha$-SMA expression and decreased E-cadherin at late time points (Figure 1D) in HRPTECs. Total AMPK (Figure 1, A, C, and E), AMPK $\alpha 1$, and AMPK $\alpha 2$ (Figure 1, A and C) levels did not change after TGF- $\beta 1$ treatment.

\section{Inhibition of AMPK Enhances Basal and}

TGF- $\beta 1-$ Induced Fibronectin, Enhances $\alpha$-SMA Expression, and Suppresses E-Cadherin Expression

To determine whether inactivation of AMPK mediates TGF$\beta 1-$ induced fibronectin expression and EMT, PTECs were exposed to TGF- $\beta 1$ in the absence or presence of the AMPK inhibitor ARA. Interestingly, ARA and TGF- $\beta 1-$ treated cells have reduced expression of E-cadherin and enhanced fibronectin and $\alpha$-SMA expression (Figure 2, A and B).

To further confirm the role of AMPK in TGF- $\beta 1$-induced EMT, PTECs were transfected with siRNA for AMPK $\alpha 1$ or siRNA for AMPK $\alpha 2$. Similar to the effect of ARA, deficiency of AMPK $\alpha 1$ or $\alpha 2$ enhanced basal and TGF- $\beta 1$-induced fibronectin and $\alpha$-SMA levels compared with control cells (Figure 2, C and D). E-cadherin protein expression was markedly reduced by the knockdown of AMPK $\alpha 1$ or $\alpha 2$ alone and decreased further in cells treated with TGF- $\beta 1$ (Figure 2C). Interestingly, immunoprecipitation/immunoblotting studies indicated that ARA decreased the phosphorylation on Thr172 


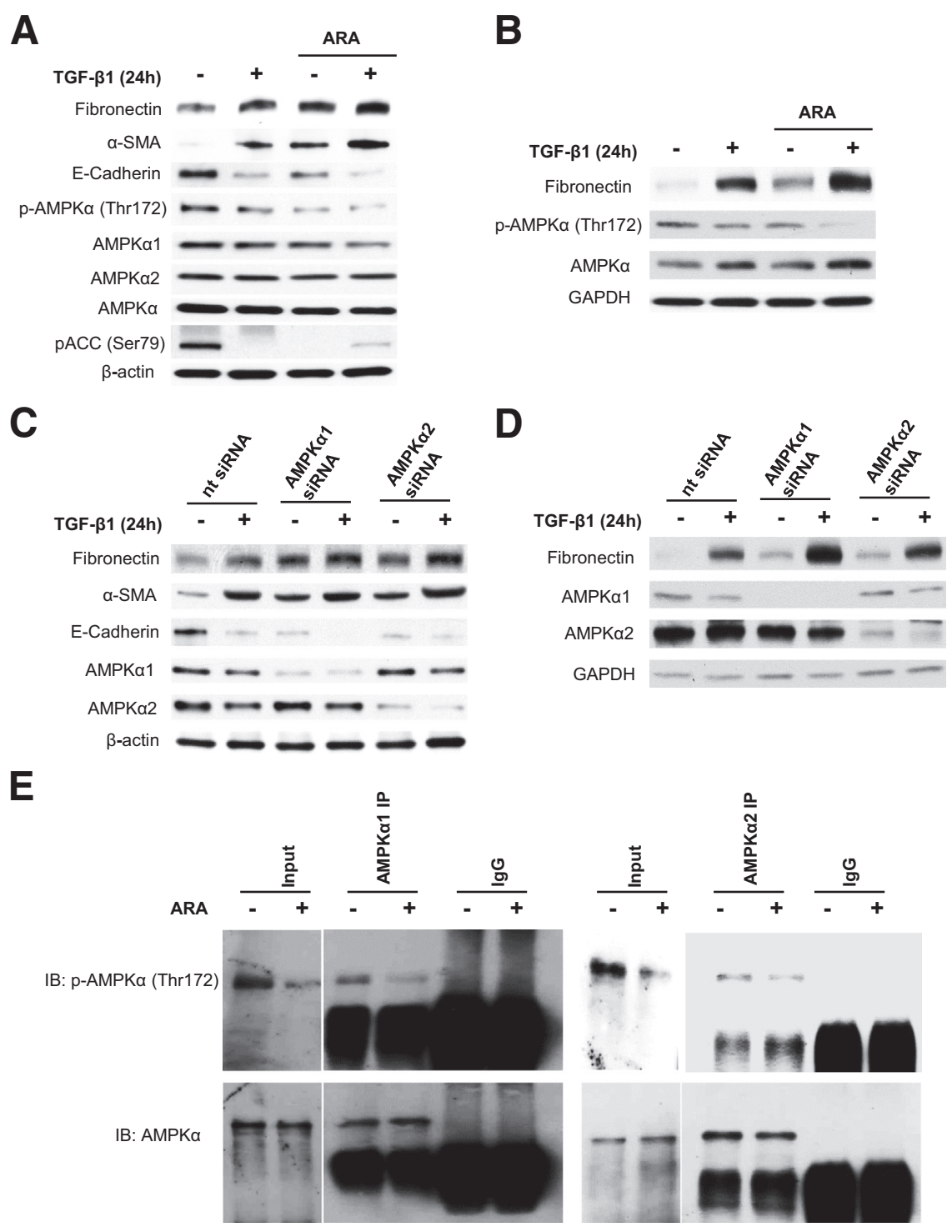

Figure 2 Inhibition or deficiency of AMPactivated protein kinase (AMPK) enhances basal and transforming growth factor (TGF)- $\beta 1$-induced fibronectin and $\alpha$-smooth muscle actin ( $\alpha$-SMA) expression and suppresses E-cadherin expression. Quiescent human renal proximal tubular epithelial cells (HRPTECS) (A) and murine kidney proximal tubular epithelial (MCT) cells (B) were pretreated with $0.5 \mathrm{mmol} / \mathrm{L}$ adenine $9-\beta$-D-arabinofuranoside (ARA) for 30 minutes followed by $1 \mathrm{ng} / \mathrm{mL}$ of TGF- $\beta 1$ treatment for 24 hours. Cell lysates were immunoblotted with fibronectin, p-AMPK $\alpha$ (Thr172), AMPK $\alpha 1, A M P K \alpha 2$, and AMPK $\alpha$ antibodies in addition to $\alpha$-SMA and E-cadherin antibodies for HRPTECs lysates. Glyceraldehyde-3-phosphate dehydrogenase (GAPDH) was used as a loading control. HRPTECs (C) and MCT (D) cells were transfected with nontargeting (nt) or AMPK $\alpha 1$ and AMPK $\alpha 2$ siRNA (specific for mouse and human) for 24 hours. Cells were serum starved for 16 hours before $1-\mathrm{ng} / \mathrm{mL}$ TGF- $\beta 1$ treatment for 24 hours. Cell lysates were immunoblotted with fibronectin, AMPK $\alpha 1$, and AMPK $\alpha 2$ antibodies, in addition to $\alpha$-SMA and E-cadherin antibodies for HRPTECs lysates. GAPDH was used as a loading control. Blots are representative of three independent experiments. E: Quiescent HRPTECs were pretreated with $0.5 \mathrm{mmol} / \mathrm{L}$ ARA for 30 minutes. Protein extracts were immunoprecipitated (IP) with AMPK $\alpha 1$, AMPK $\alpha 2$ antibody, or normal rabbit IgG and proteinA agarose suspension. Immune complexes were collected and analyzed by immunoblotting (IB) with p-AMPK $\alpha$ (Thr172) or total AMPK $\alpha$ antibodies. Normal rabbit IgG was used as a control. Blots are representative of two independent experiments. of AMPK $\alpha 1$ and AMPK $\alpha 2$ (Figure 2E), suggesting that both AMPK $\alpha$ isoforms are targeted and inhibited by ARA. This finding is consistent with the finding that siRNA for AMPK $\alpha 1$ and siRNA for AMPK $\alpha 2$ influence the effects of TGF- $\beta 1$. It appears that both AMPK $\alpha 1$ and AMPK $\alpha 2$ are implicated in PTECs.

Collectively, these data indicate that deficiency or inactivation of AMPK results in increases of fibronectin and $\alpha$-SMA expression, a decrease of E-cadherin expression, and a further enhancement of TGF- $\beta 1$-induced EMT phenotype.

\section{AMPK Activation Prevents the Effects of TGF- $\beta 1$ on Indices of EMT}

To determine whether activation of AMPK prevents TGF$\beta 1$-induced expression of EMT, HRPTECs were treated with the well-known AMPK agonists AICAR and metformin. AMPK activation was confirmed by enhanced phosphorylation of AMPK on Thr172 and pACC on Ser79 (Figure 3, A and B).
Activation of AMPK by AICAR or metformin markedly reduced basal and TGF- $\beta 1$-induced increase in fibronectin and $\alpha$-SMA (Figure 3, A and B). Interestingly, E-cadherin levels were increased by the activation of AMPK even in cells treated with TGF- $\beta 1$ (Figure 3, A and B).

The pharmacologic effects of AICAR and metformin were confirmed by using plasmid overexpressing wild-type AMPK $\alpha 2$ and GFP tagged constitutively active AMPK adenovirus (AdCA-AMPK $\gamma$ ). Wild-type AMPK $\alpha 2$ or AdCAAMPK $\gamma$ markedly reduced basal and TGF- $\beta 1-$ induced increase in fibronectin expression (Figure 3, C-E). These data indicate that AMPK activation negatively regulates EMT.

Moreover, immunoprecipitation/immunoblotting data revealed that AICAR enhances phosphorylation of both AMPK $\alpha 1$ and AMPK $\alpha 2$ on Thr172, suggesting that both AMPK $\alpha 1$ and AMPK $\alpha 2$ were activated by AICAR in PETCs (Figure 3F).

These observations were confirmed by immunofluorescence studies. Immunofluorescence analysis in PTECs revealed a 
A

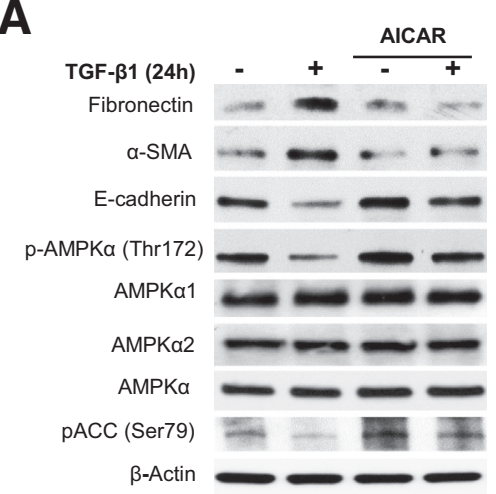

C

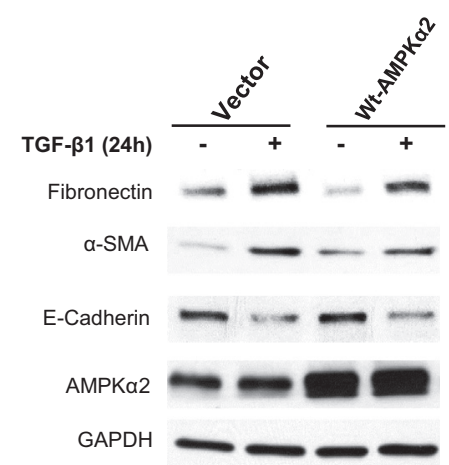

B

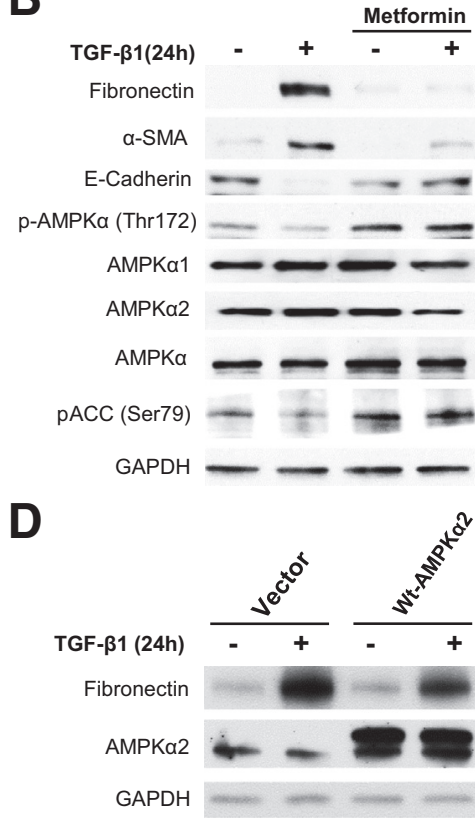

E

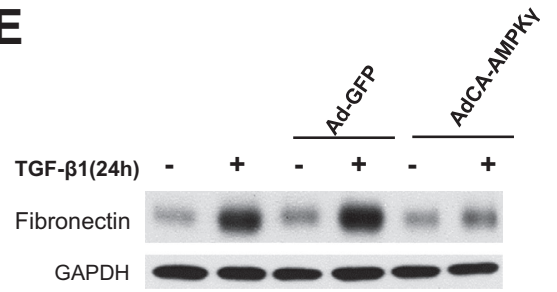

$\mathbf{F}$

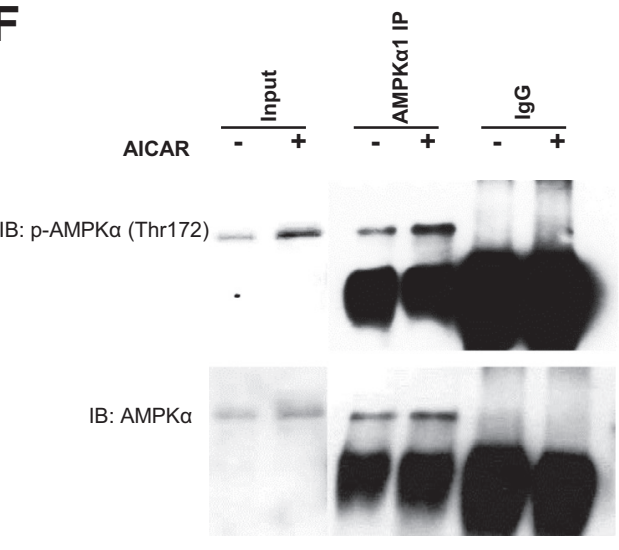

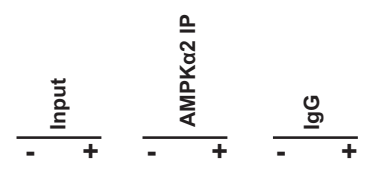

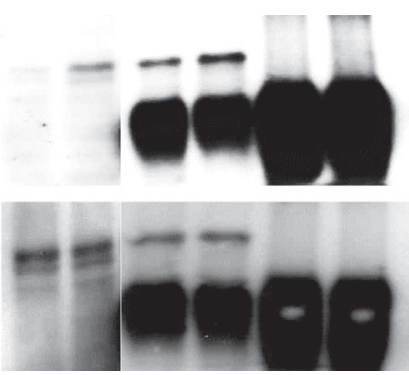

Figure 3 Activation of AMP-activated protein kinase (AMPK) prevents the effects of transforming growth factor (TGF)- $\beta 1$. A and B: Quiescent human renal proximal tubular epithelial cells (HRPTECS) were pretreated with $1 \mathrm{mmol} / \mathrm{L} 5$-aminoimidazole-4carboxamide $1-\beta$-D-ribofuranoside (AICAR) or 1 $\mathrm{mmol} / \mathrm{L}$ metformin for 30 minutes followed by 1-ng/ mL TGF- $\beta 1$ treatment for 24 hours. Cell lysates were immunoblotted with fibronectin, $\alpha$-smooth muscle actin ( $\alpha$-SMA), E-cadherin, p-AMPK $\alpha$ (Thr172), AMPK $\alpha 1$, AMPK $\alpha 2$, AMPK $\alpha$, and phospho-acetyl carboxylase coenzyme-A (pACC) (Ser79) antibodies. Glyceraldehyde-3-phosphate dehydrogenase (GAPDH) was used as loading control. Blots are representative of three independent experiments. In parallel experiments, HRPTECs (C) and murine kidney proximal tubular epithelial (MCT) cells (D) were transfected with empty vector or wild-type (WT)-AMPK $\alpha 2$ vector. Cells were serum starved for 16 hours before $1-\mathrm{ng} / \mathrm{mL}$ TGF- $\beta 1$ treatment for 24 hours. Cell lysates were immunoblotted with fibronectin, $\alpha$-SMA, E-cadherin, and AMPK $\alpha 2$ antibodies. GAPDH was used as a loading control. Blots are representative of two independent experiments. E: MCT cells were infected with adenovirus encoding constitutively active (AdCA) AMPK $\gamma$ at a multiplicity of infection of 50 for 24 hours. The green fluorescent protein vector (Ad-GFP) was used as experimental control. Cells were serum starved for 16 hours before 1-ng/ $\mathrm{mL}$ TGF- $\beta 1$ treatment for 24 hours. Cell lysates were immunoblotted with fibronectin and GAPDH antibodies. Blots are representative of two independent experiments. F: Quiescent HRPTECs were pretreated with $1 \mathrm{mmol} / \mathrm{L}$ AICAR for 30 minutes. Protein extracts were immunoprecipitated (IP) with AMPK $\alpha 1$, AMPK $\alpha 2$ antibody, or normal rabbit IgG and protein-A agarose suspension. Immune complexes were collected and analyzed by immunoblotting (IB) with $\mathrm{p}-\mathrm{AMPK} \alpha$ (Thr172) or total AMPK $\alpha$ antibodies. Normal rabbit IgG was used as a control. Blots are representative of two independent experiments. marked increase in fibronectin and $\alpha$-SMA expression in the TGF- $\beta 1-$ treated cells when compared with control and was markedly reduced by the AMPK agonist AICAR (Figure 4, $\mathrm{A}-\mathrm{F}, \mathrm{J}-\mathrm{O}$ ). Immunofluorescence localization of E-cadherin in both human and mouse PTECs revealed reduced expression in TGF- $\beta 1$-treated cells, and their levels were increased in AICAR/TGF- $\beta 1$-treated cells (Figure 4, G-I, P-R).

\section{AMPK Modulates the mRNA Expression of the Fibrotic Injury and EMT Markers in Response to TGF- $\beta 1$}

Fibronectin, $\alpha$-SMA, and E-cadherin mRNAs were measured by quantitative real-time RT-PCR (RT-qPCR) on RNA extracted from HRPTECs treated with TGF- $\beta 1$ in the presence or absence of ARA or AICAR. Similar to what is observed for the protein expression, fibronectin and $\alpha$-SMA mRNA levels also significantly increased (Figure 5, A and B), whereas E-cadherin mRNA levels decreased (Figure $5 \mathrm{C}$ ) in response to TGF- $\beta 1$ treatments compared with control. Pretreatment of the cells with ARA mimicked the effects of TGF- $\beta 1$ on fibronectin, $\alpha$-SMA, and E-cadherin mRNA expression (Figure 5, A-C). Results also revealed that a TGF- $\beta 1-$ mediated increase in fibronectin and $\alpha$-SMA mRNAs and a TGF- $\beta 1$-induced decrease in E-cadherin mRNA levels were blocked by AICAR treatment (Figure 5, A-C). 


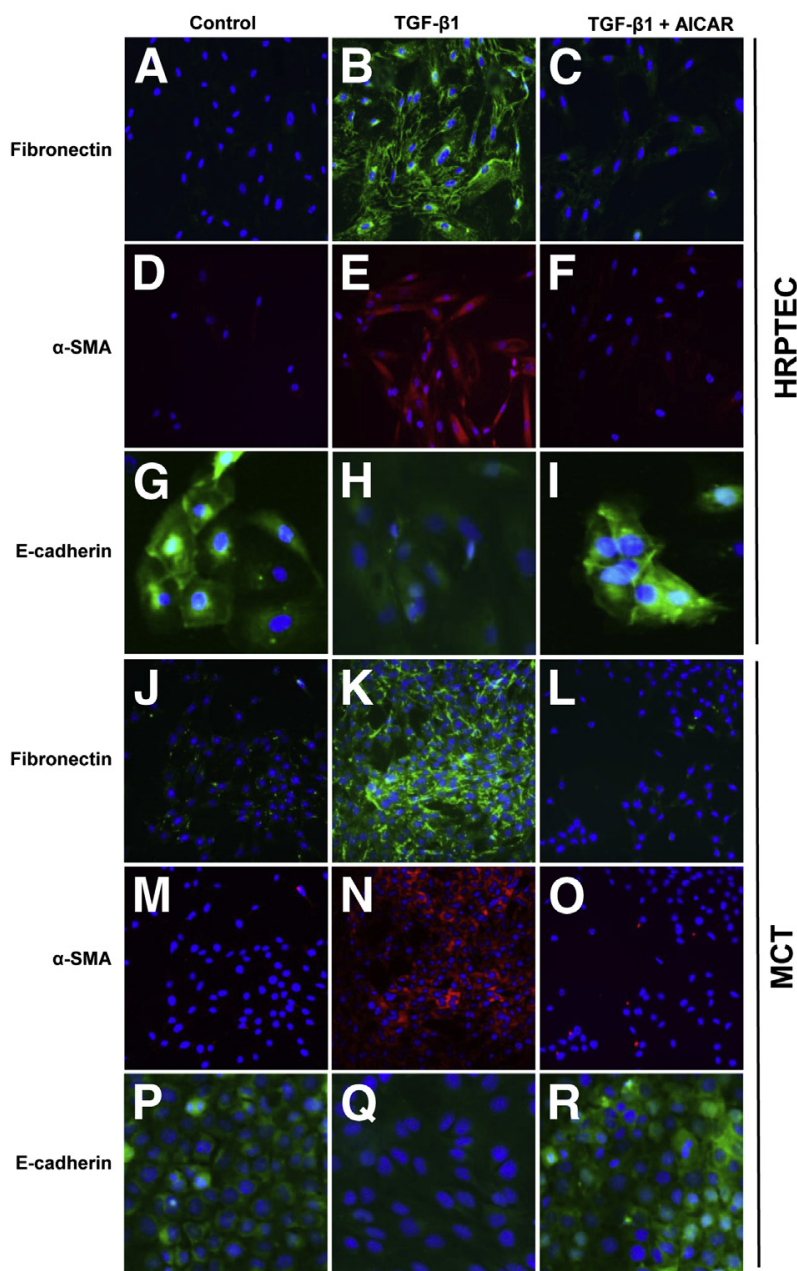

Figure 4 Immunofluorescence analyses confirms that AMP-activated protein kinase (AMPK) activation inhibits transforming growth factor (TGF)$\beta 1$-induced fibronectin and $\alpha$-smooth muscle actin ( $\alpha$-SMA) expression and down-regulation of E-cadherin in proximal tubular epithelial cells (PTECS). Quiescent human renal PTECs (HRPTECS) (A-I) and murine kidney proximal tubular epithelial (MCT) cells $(\mathbf{J}-\mathbf{R})$ were pretreated with $1 \mathrm{mmol} / \mathrm{L} 5$ aminoimidazole-4-carboxamide 1- $\beta$-D-ribofuranoside (AICAR) for 30 minutes followed by $1-\mathrm{ng} / \mathrm{mL}$ TGF- $\beta 1$ treatment for 24 hours. Cells were immunostained with fibronectin (green), $\alpha$-SMA (red), and E-cadherin (green) antibodies. Nuclei were stained with DAPI (blue). Original magnification: $\times 200$.

\section{AMPK Inhibits TGF- $\beta 1-$ Induced Matrix Accumulation in Interstitial Fibroblasts}

To determine the role of AMPK in interstitial fibrosis, NRK49F cells were treated with $1 \mathrm{ng} / \mathrm{mL}$ of TGF- $\beta 1$ for short- or long-term incubations and also in the absence or presence of AMPK activators/inhibitors for 24 hours. TGF- $\beta 1$ treatment causes a decrease in AMPK phosphorylation on its activating site (Thr172) that is associated with increased fibronectin and $\alpha$-SMA expression (Figure 6A). Inhibition of AMPK with ARA or infection of the cells with dominant negative AMPK $\alpha 2$ enhanced basal and TGF- $\beta 1$-induced phenotypic changes (Figure 6B). Conversely, activation of AMPK by AICAR or metformin markedly attenuated the phenotypic changes induced by TGF- $\beta 1$ as assessed by Western blot and immunofluorescence analyses (Figure 6, C and D). The expression of fibronectin and $\alpha$-SMA mRNA and protein was analyzed by qPCR. Similar to PTECs, AMPK inhibition with ARA reproduced the stimulatory effects of TGF- $\beta 1$ on fibronectin and $\alpha$-SMA mRNA expression and AMPK activation with AICAR inhibited TGF- $\beta 1-$ induced increased in fibronectin and $\alpha$-SMA mRNA expression (Figure 6E).
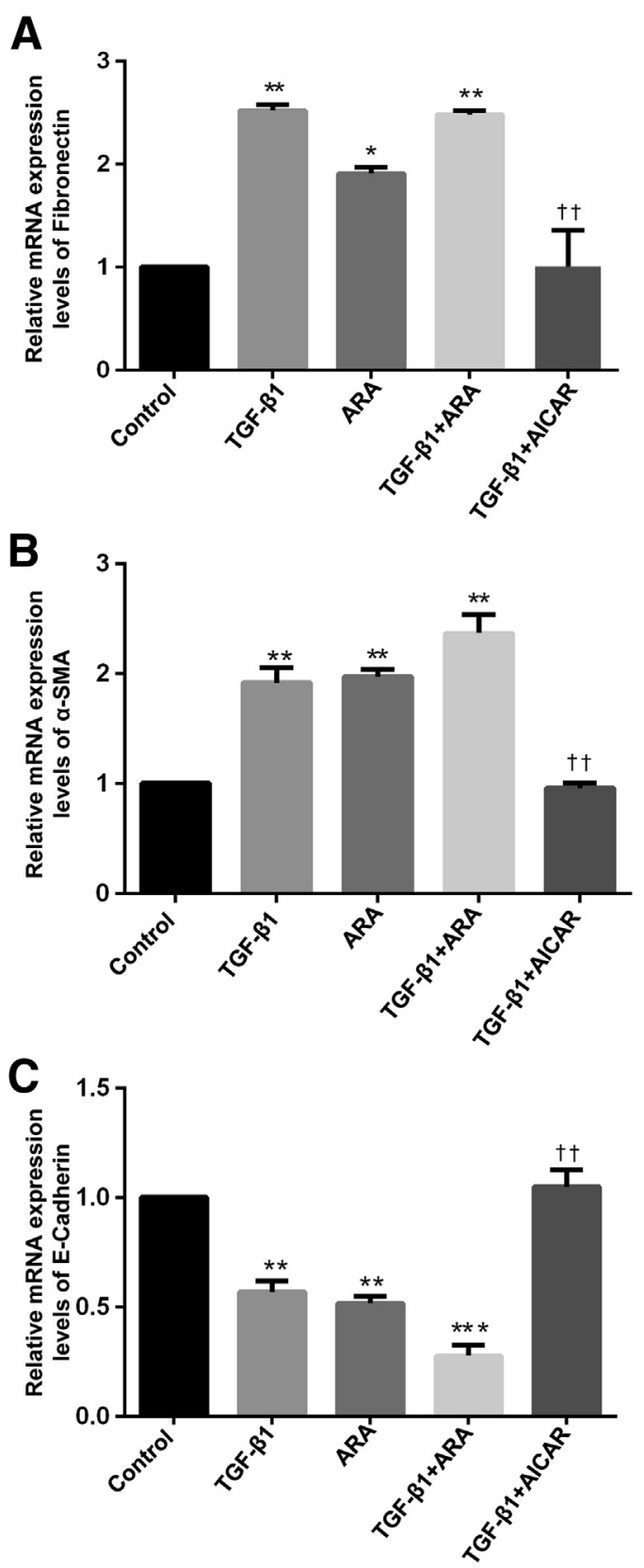

Figure 5 AMP-activated protein kinase (AMPK) modulates transforming growth factor (TGF)- $\beta 1$-induced regulation of fibronectin, $\alpha$-smooth muscle actin ( $\alpha$-SMA), and E-cadherin at the mRNA levels. Fibronectin (A), $\alpha$-SMA (B), and E-cadherin (C) mRNAs were measured by quantitative RT-PCR on RNA extracted from human renal proximal tubular epithelial cells (HRPTECS) treated with TGF- $\beta 1$ in the presence or absence of adenine $9-\beta$-D-arabinofuranoside (ARA) or 5-aminoimidazole-4-carboxamide 1- $\beta$-D-ribofuranoside (AICAR) and normalized using glyceraldehyde-3-phosphate dehydrogenase as a housekeeping gene. ${ }^{*} P<0.05,{ }^{* *} P<0.01,{ }^{* * *} P<0.001$ versus control by analysis of variance; ${ }^{\dagger} P<0.01$ versus TGF- $\beta 1$ by analysis of variance. 

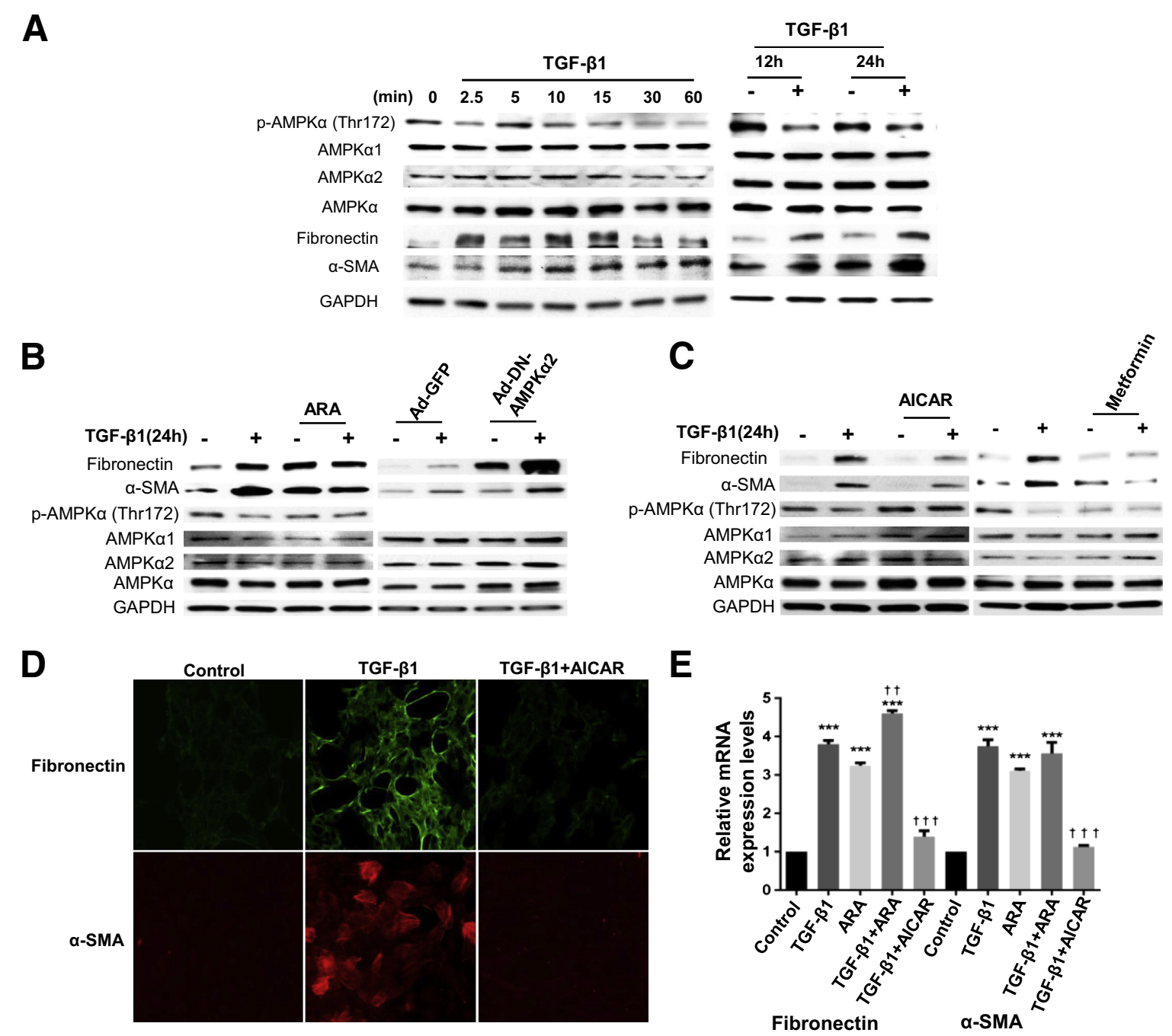

Figure 6 AMP-activated protein kinase (AMPK) inhibits transforming growth factor (TGF)- $\beta 1$-induced matrix accumulation in normal rat kidney interstitial fibroblasts. A: Quiescent cells were stimulated with $1 \mathrm{ng} / \mathrm{mL}$ of TGF- $\beta 1$ for the indicated periods. Cell lysates were immunoblotted with fibronectin, $\alpha$-smooth muscle actin $(\alpha-S M A), p-A M P K \alpha$ (Thr172), and AMPK $\alpha$ antibodies. Glyceraldehyde-3-phosphate dehydrogenase (GAPDH) was used as a loading control. Blots are representative of three independent experiments. B: Quiescent cells were pretreated with $0.5 \mathrm{mmol} / \mathrm{L}$ adenine $9-\beta$-D-arabinofuranoside (ARA) for 30 minutes followed by 1 -ng/mL TGF- $\beta 1$ treatment for 24 hours. Cell lysates were immunoblotted with fibronectin, $\alpha$-SMA, p-AMPK $\alpha$ (Thr172), and AMPK $\alpha$ antibodies. GAPDH was used as a loading control (left panel). Cells were infected with adenovirus encoding dominant negative AMPK (Ad-DN-AMPK) at a multiplicity of infection of 50 for 24 hours. The green fluorescent protein vector (Ad-GFP) was used as experimental control. Cells were serum starved for 16 hours before $1-\mathrm{ng} / \mathrm{mL}$ TGF- $\beta 1$ treatment. Cell lysates were immunoblotted with fibronectin, $\alpha$-SMA, AMPK, and GAPDH antibodies (right panel). Blots are representative of two independent experiments. C: Quiescent cells were pretreated with 1 $\mathrm{mmol} / \mathrm{L} 5$-aminoimidazole-4-carboxamide 1- $\beta$-D-ribofuranoside (AICAR) or $1 \mathrm{mmol} / \mathrm{L}$ metformin for 30 minutes followed by 1-ng/mL TGF- $\beta 1 \mathrm{treatment} \mathrm{for} 24 \mathrm{hours}$. Cell lysates were immunoblotted with fibronectin, $\alpha$-SMA, p-AMPK $\alpha$ (Thr172), and AMPK $\alpha$ antibodies. GAPDH was used as a loading control. Blots are representative of three independent experiments. D: Quiescent cells were pretreated with $1 \mathrm{mmol} / \mathrm{L}$ AICAR for 30 minutes followed by $1-\mathrm{ng} / \mathrm{mL}$ TGF- $\beta 1$ treatment for 24 hours. Cells were immunostained with fibronectin (green) and $\alpha$-SMA (red) antibodies. Nuclei were stained with DAPI (blue). E: Fibronectin and $\alpha$-SMA mRNAs were measured by quantitative RT-PCR on RNA extracted from cells treated with TGF- $\beta 1$ in the presence or absence of ARA or AICAR. ${ }^{* * *} P<0.001$ versus control by analysis of variance; ${ }^{\dagger \dagger} P<0.01,{ }^{\dagger \dagger} P<0.001$ versus TGF- $\beta 1$ by analysis of variance.

\section{Tuberin Inhibits Matrix Accumulation and EMT Marker Expression in PTECs}

AMPK activates tuberin via direct phosphorylation on specific residues, including Ser1387. ${ }^{19,20}$ Therefore, we investigated the role of tuberin as a potential mediator of AMPK actions in HRPTECs and MCT cells. Short and prolonged exposure of HRPTECs and MCT cells to TGF- $\beta 1$ causes a decrease in tuberin phosphorylation on Ser1387, an AMPK-dependent activating site (Figure 7, A and B). We next investigated the functional association between tuberin and extracellular matrix accumulation and EMT marker expression. Knockdown of tuberin with siRNA enhances basal fibronectin protein expression and TGF- $\beta 1$-induced fibronectin synthesis in HRPTECs and MCT cells (Figure 7, C and D) and decreases E-cadherin expression in HRPTECs (Figure 7C). To further confirm that tuberin inactivation is associated with increased matrix protein expression, we determined the basal levels of fibronectin in 


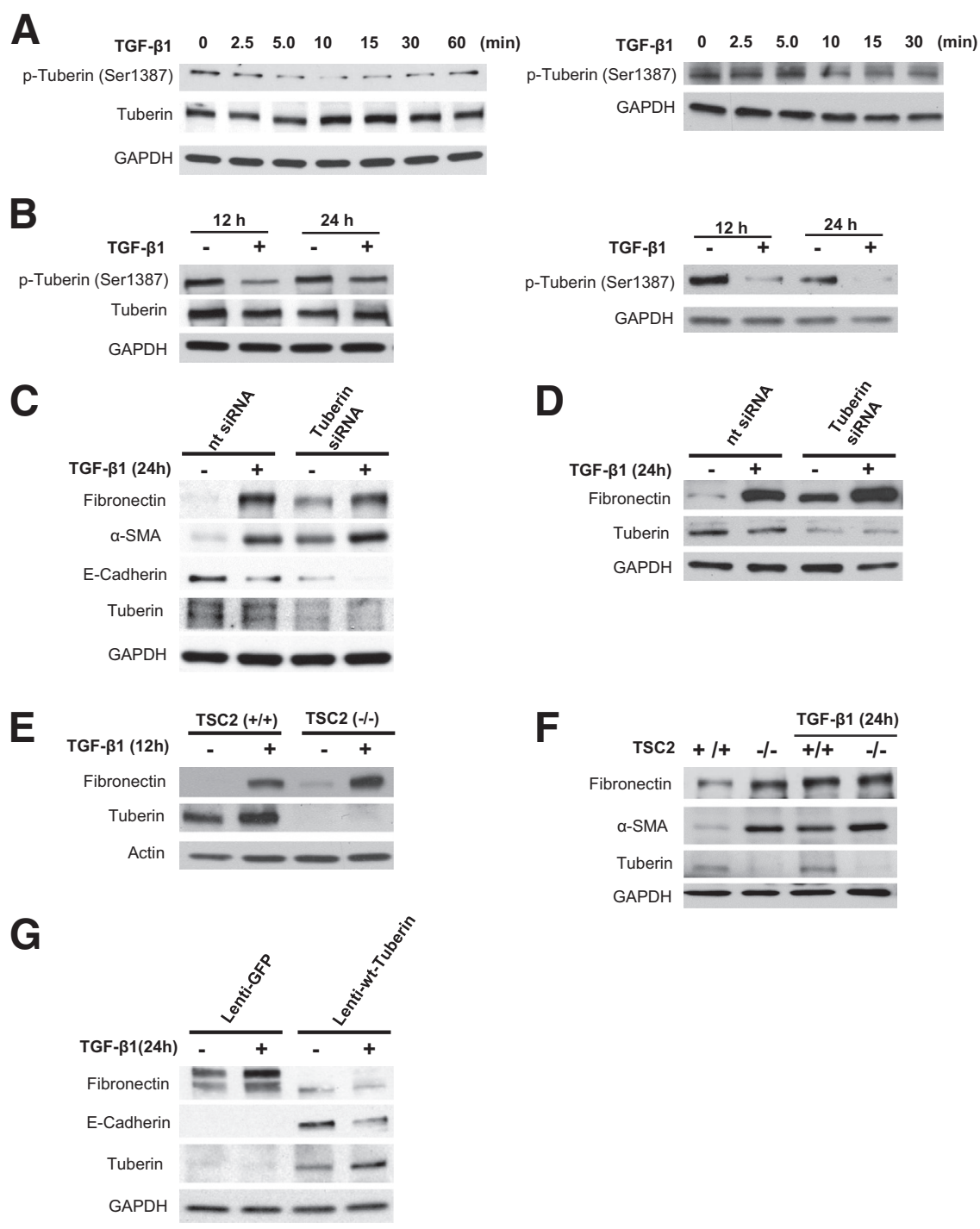

Figure 7 Functional associations among AMPactivated protein kinase (AMPK), tuberin, and fibrotic injury in renal cells. A: Treatment of human renal proximal tubular epithelial cells (HRPTECs) and murine kidney proximal tubular epithelial (MCT) cells for short periods with $1 \mathrm{ng} / \mathrm{mL}$ of transforming growth factor (TGF)- $\beta 1$ decreases tuberin phosphorylation on its AMPK-dependent activation site (Ser1387). B: Prolonged exposure of HRPTECs and MCT cells to $1 \mathrm{ng} / \mathrm{mL}$ of TGF- $\beta 1$ for 24 hours also decreases tuberin phosphorylation on Ser1387. C and D: Knockdown of tuberin with specific siRNA (TuberinsiRNA) enhances basal and TGF- $\beta 1$ ( $1 \mathrm{ng} /$ $\mathrm{mL}, 24$ hours)-mediated increase in fibronectin expression and basal and TGF- $\beta 1$-induced decrease in E-cadherin in HRPTECs (C) and MCT cells (D). E and $\mathbf{F}$ : Representative immunoblots reveal that basal and TGF- $\beta 1$ ( $1 \mathrm{ng} / \mathrm{mL}, 12$ or 24 hours)-induced increase in fibronectin expression and $\alpha$-SMA are higher in tuberin-null mouse embryonic fibroblast cells (MEFs) $\left(T s C 2^{-/-}\right)$compared with wild-type (wt) MEFs $\left(T s c 2^{+/+}\right)$. Glyceraldehyde-3-phosphate dehydrogenase (GAPDH) was used as loading control for Western blot. G: Representative immunoblots show that introduction of tuberin in $\mathrm{TsC2}^{-/-}$LExF2 cells with a lentiviral vector (Lenti-wt-Tuberin) is accompanied by a decrease in fibronectin expression and an increase in E-cadherin expression. A lentivirus expressing GFP (Lenti-GFP) was used as a control. Blots are representative of three independent experiments $(\mathbf{A}-\mathbf{G})$. Nt siRNA, nontargeting control siRNA.

tuberin-null $\left(T s c 2^{-/-}\right)$mouse embryonic fibroblast cells (MEFs). Total deficiency of tuberin in the null cells was associated with a marked increase in fibronectin and $\alpha$-SMA expression (Figure 7, E and F). The siRNA-mediated knockdown of tuberin in HRPTECs and MCT cells or the absence of tuberin in MEFs did not significantly enhance TGF$\beta 1-$ mediated increase in fibronectin and $\alpha$-SMA (Figure 7, C-F). In $T s c 2^{-/-}$LExF2 cells (derived from epithelial tumors of Eker rats), fibronectin protein levels are elevated and no Ecadherin expression was detectable. Transduction of the TSC2-null lymphoid-enhancing factor cells with lentivirus containing wild-type tuberin resulted in a marked decrease in fibronectin expression and an increase in E-cadherin protein expression (Figure 7G).

\section{AMPK in Alb/TGF- $\beta 1$ Transgenic Mice}

Kidney lysates from Alb/TGF- $\beta 1$ transgenic mice were used to study the role of AMPK and tuberin in regulation of fibrogenic response induced by TGF- $\beta 1$. The expression of fibronectin,
$\alpha$-SMA, and E-cadherin proteins were analyzed by Western blotting and IHC. The data indicate that in mice overexpressing TGF- $\beta 1$ the reduction in AMPK phosphorylation on its activating site (Thr172) and the reduction in tuberin phosphorylation on AMPK-dependent activating site (Ser1387) are associated with increased fibronectin and $\alpha$-SMA expression and reduced E-cadherin compared with wild-type mice (Figure 8, A-C and E). RNA extracted from tissues was also analyzed for fibronectin and $\alpha$-SMA mRNA levels; robust increase was observed when compared with wild-type mouse kidney lysates (Figure 8D).

\section{Discussion}

In this study, using tubular epithelial cells derived from human and murine kidneys, we describe a rather simple mechanism, inhibition of AMPK, by which TGF- $\beta 1$ induces mesenchymal cell characteristics suggestive of type II EMT (Figure 9). TGF$\beta 1$ uses a similar mechanism to activate fibroblasts and promote 
A

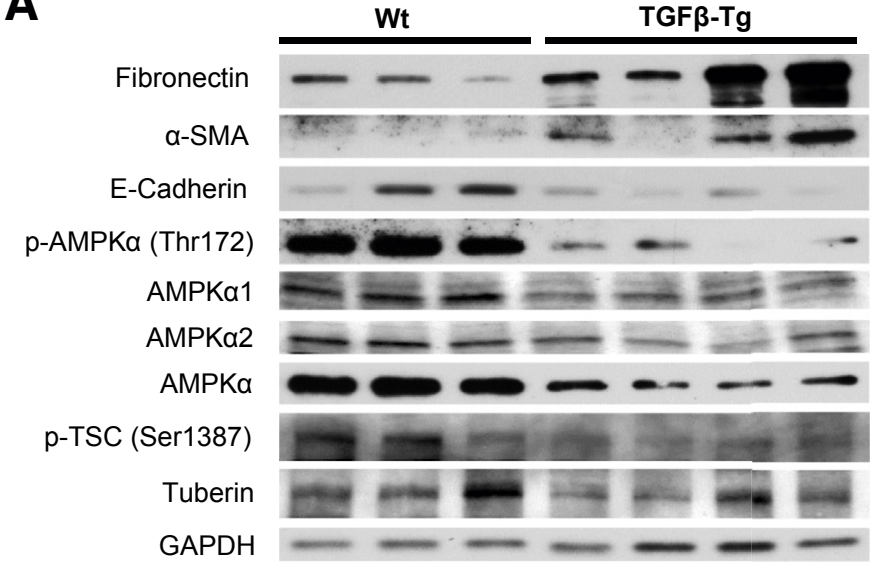

B
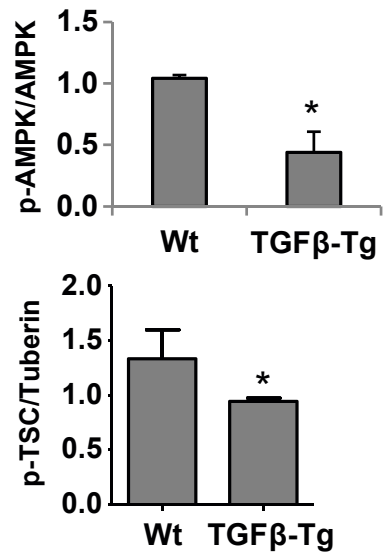

C
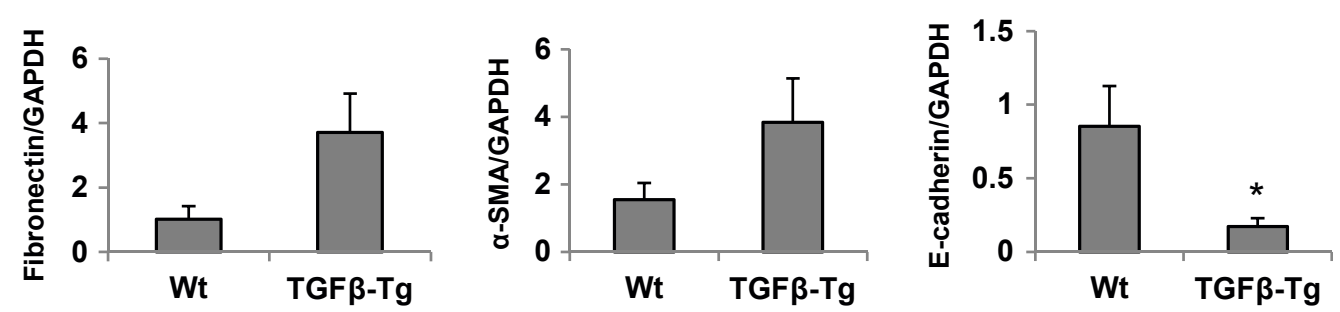

D
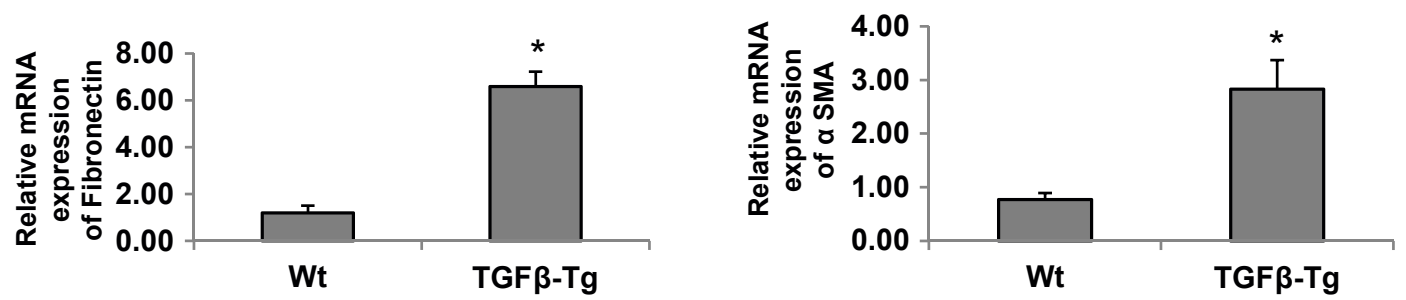

E
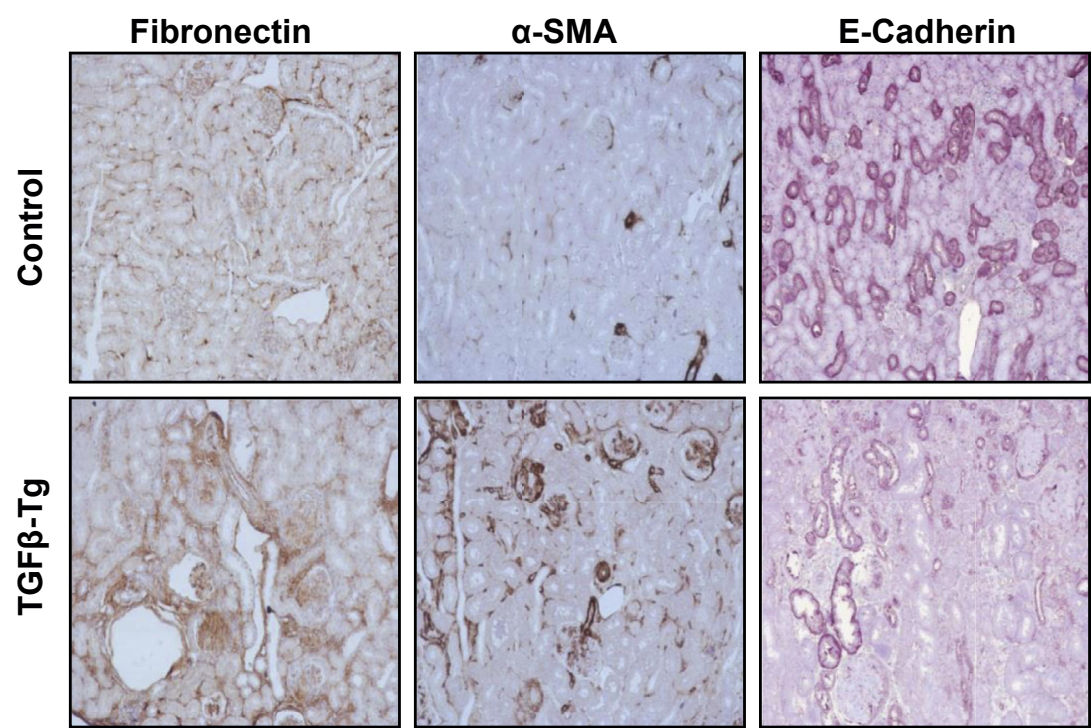

Figure 8 Kidney cortex of transforming growth factor (TGF)- $\beta$ transgenic mice reveals decreased AMP-activated protein kinase (AMPK) phosphorylation associated with increase in mesenchymal markers. A: Kidney homogenates from wild-type (Wt) and TGF- $\beta$ transgenic mice (TGF- $\beta$-Tg) were immunoblotted with fibronectin, $\alpha$-smooth muscle actin ( $\alpha$-SMA), E-cadherin, p-AMPK $\alpha$ (Thr172), p-Tuberin (Ser1387), AMPK $\alpha 1$, AMPK $\alpha 2$, AMPK $\alpha$, and tuberin antibodies. Glyceraldehyde-3-phosphate dehydrogenase (GAPDH) was used as a loading control. B and C: Densitometric analysis of the immunoblots. D: Fibronectin and $\alpha$-SMA mRNA expression was measured by quantitative RT-PCR and normalized using GAPDH as a housekeeping gene. E: Fibronectin, $\alpha$-SMA, and E-cadherin protein expression were detected by immunohistochemistry on sections of paraffin-embedded kidneys. ${ }^{*} P<0.05$. Original magnification: $\times 100$. 


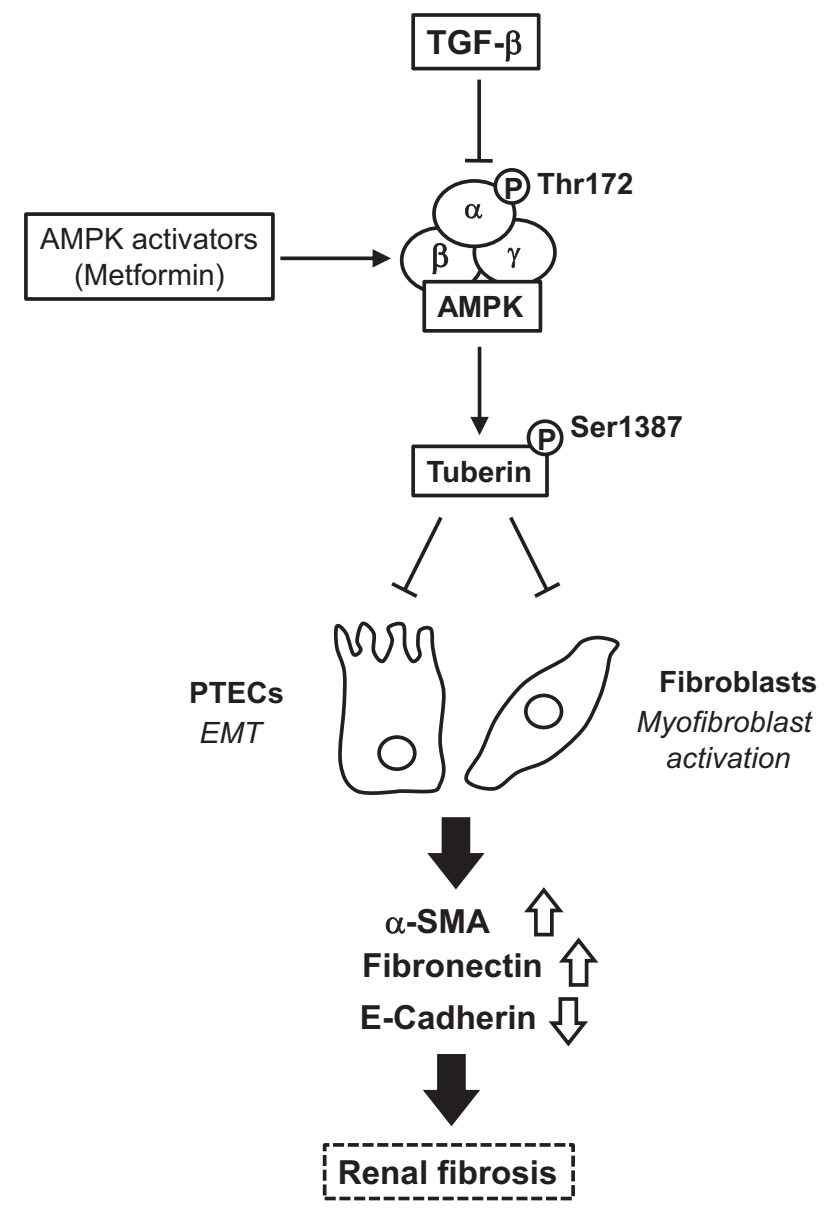

Figure 9 Schematic diagram of transforming growth factor (TGF)$\beta 1-$ induced epithelial mesenchymal transition and renal fibrosis through inhibition of AMP-activated protein kinase (AMPK). $\alpha$-SMA, $\alpha$-smooth muscle actin; EMT, epithelial-mesenchymal transition; PTECs, proximal tubular epithelial cells.

their transition to myofibroblasts. The role of AMPK is established by the following observations: TGF- $\beta 1$ inactivates AMPK by decreasing its phosphorylation on the active site Thr172 and enhances the expression of fibronectin and $\alpha$-SMA but decreases the expression of E-cadherin. Pharmacologic or genetic activation of AMPK reverses the effects of TGF- $\beta 1$, whereas inhibition of AMPK mimics the effect of TGF- $\beta 1$ and potentiates the phenotypic changes induced by TGF- $\beta 1$. Importantly, tuberin connects AMPK to extracellular matrix synthesis and fibrotic response in renal epithelial cells. Furthermore, the in vivo relevance of these findings is indicated by experiments in the kidney cortex of TGF- $\beta 1$ transgenic mice in which a significant decrease in AMPK and tuberin phosphorylation on activating sites is associated with an increase in mesenchymal markers and decrease in E-cadherin.

Tubulointerstitial fibrosis is a major determinant of the rate of decline of kidney function in progressive kidney diseases. ${ }^{21}$ Tubular epithelial cell injury and fibroblast activation contribute to the pathogenesis of tubulointerstitial fibrosis and are major manifestations of progressive kidney disease. In addition to apoptosis and atrophy, renal epithelial cell injury may manifest as acquisition of mesenchymal characteristics sometimes referred to as type II EMT. ${ }^{22,23}$ EMT typically occurs in response to environmental factors, including profibrotic cytokines and growth factors. ${ }^{24,25}$ TGF$\beta 1$ is a potent inducer of EMT and mediates key tubular pathologic events in the course of progressive kidney disease. TGF- $\beta 1-$ mediated EMT involves a complex interplay of signaling pathways in different cellular systems and is mediated by both canonical (Smad2/3-dependent) and noncanonical (p38MAPK, ERK, JNK, PI3K/Akt) signaling pathways. ${ }^{26}$

As previously reported by others, ${ }^{27-30}$ we find that treatment of primary HRPTECs with TGF- $\beta 1$ increases fibronectin and $\alpha$-SMA expression and down-regulates E-cadherin. Importantly, TGF- $\beta 1$ reduces AMPK phosphorylation on its activating site Thr172. The precise mechanisms by which TGF- $\beta 1$ suppresses AMPK phosphorylation needs to be explored. It is possible that TGF- $\beta 1$ acts through the SMAD3dependent pathway to transcriptionally up-regulate phosphatases and decrease AMPK phosphorylation. We and others have reported that AMPK phosphorylation and activity are decreased in glomerular epithelial and mesangial cells treated with high glucose or in renal cortex of type 1 diabetic rats and mice. ${ }^{14,31-33}$ In glomerular epithelial cells, AMPK inactivation by high glucose was due to a decrease in the activity of its upstream protein kinase LKB1. ${ }^{14,32}$ An inhibitory effect of LKB1 by TGF- $\beta$ in tubular cells and renal fibroblast is conceivable and needs to be further explored. Because TGF$\beta 1$ is up-regulated in the kidney cortex in progressive fibrotic renal diseases, including diabetic nephropathy, it is likely that it contributes to tubulointerstitial fibrosis by inhibiting AMPK in both tubular epithelial cells and interstitial fibroblasts. A recent study described a similar process in mesangial cells exposed to TGF- $\beta .^{34}$ Therefore, TGF- $\beta$-dependent AMPK inactivation appears to be a rather ubiquitous mechanism used by TGF- $\beta$ to exert its deleterious actions in the kidney. These observations are clinically relevant because they suggest that therapeutic targeting of AMPK affords protection of both glomerular and tubular compartments by preventing glomerular and tubulointerstitial cell injury.

We also found that activation of AMPK with AICAR or metformin markedly reduced TGF- $\beta 1$-induced fibronectin and $\alpha$-SMA expression and prevented the decrease in E-cadherin expression. The inhibitory role of active AMPK on induction of the EMT phenotype was further revealed by genetic approaches using adenoviral transduction of constitutively active mutant of AMPK or by overexpression of wild-type AMPK $\alpha 2$ in the cells. Conversely, inhibition of AMPK with ARA or siRNA knockdown of AMPK increased matrix protein expression and further potentiated the effects of TGF- $\beta 1$. Interestingly, the siRNA data and to some extent the immunoprecipitation/ immunoblotting studies suggest that AMPK $\alpha$ isoforms $\alpha 1$ and $\alpha 2$ are implicated in the effects of TGF- $\beta 1$. This finding implies that potential therapeutic interventions restoring AMPK activity need to target both AMPK $\alpha$ isoforms to be optimally effective.

Importantly, we provide evidence that tuberin functions as a key mediator of AMPK inhibitory effects on extracellular 
matrix synthesis and EMT marker expression. Tuberin and its phosphorylation by AMPK protect renal cells from fibrotic injury and EMT. Our data also suggest that inactivation of AMPK by TGF- $\beta 1$ suppresses AMPK-dependent tuberin phosphorylation and activation, resulting in excessive matrix protein synthesis. Although the connection between tuberin and matrix protein accumulation was previously found in the kidney, ${ }^{35}$ to the best of our knowledge, it the first time that a role for AMPK-dependent tuberin regulation in fibrotic injury has been reported.

AMPK appears to regulate mesenchymal and epithelial markers at the mRNA and protein level, suggesting enhanced transcription. However, changes in mRNA stability cannot be excluded. Moreover, we found that TGF- $\beta 1$ also causes a rapid increase in fibronectin and $\alpha$-SMA expression (as early as 5 to 10 minutes). It is likely that in these periods transcriptional mechanisms are not implicated and that translational events may also account for the acute profibrotic actions of TGF- $\beta 1$. This type of regulation was observed with other mediators of renal cell fibrotic response, such as glucose and angiotensin II, ${ }^{33,36-38}$ but was not described in the case of TGF- $\beta$. There are few reports of regulation of AMPK phosphorylation by TGF- $\beta 1$, and these appear to be context and cell specific. In the human hepatoma cell line and in mouse macrophages, AMPK is activated by TGF- $\beta{ }^{39,40}$ In mouse hepatocytes on the other hand, AMPK is required for TGF- $\beta$-induced EMT. ${ }^{41}$ Activation of AMPK inhibits TGF- $\beta 1$-induced fibrogenic response in hepatic stellate cells, ${ }^{42}$ to prevent the activation of mesangial cells in response to TGF- $\beta,{ }^{43}$ and to suppresses EMT through inhibition of reactive oxygen species in human renal tubular epithelial cells. ${ }^{42,44}$ None of these studies explored the effect of TGF- $\beta$ in vivo. Our data in kidney from TGF- $\beta$ overexpressing mice clearly confirm that AMPK inhibition also occurs in vivo.

Our finding that activation of AMPK reduces tubular epithelial injury and interstitial fibroblast activation has important therapeutic implications. The present study provides a strong rational for the use of AMPK activators to treat TGF- $\beta$-associated fibrotic kidney diseases independent of their origin. This could be a promising alternative to the previously inconclusive strategies aiming to neutralize TGF- $\beta$ effects. In contrast to TGF- $\beta$ inhibitors that seem to be effective on matrix accumulation but not on albuminuria, ${ }^{45-47}$ AMPK activators reduce fibrosis and urinary protein excretion. ${ }^{14}$ Activators of AMPK, such as metformin, are approved by the U.S. Food and Drug Administration and are in clinical use for metabolic control of diabetes. Our findings suggest that metformin may exert therapeutic benefit by a direct effect on a major organ frequently targeted in diabetes and other diseases characterized by renal fibrosis.

\section{Acknowledgments}

SV-40 immortalized murine kidney PTECs were kindly provided by Dr. Eric G. Neilson. Dominant negative AMPK was a generous gift from Dr. Morris J. Birnbaum (University of Pennsylvania, Philadelphia, PA).

\section{References}

1. Liu Y: New insights into epithelial-mesenchymal transition in kidney fibrosis. J Am Soc Nephrol 2010, 21:212-222

2. Wynn TA: Common and unique mechanisms regulate fibrosis in various fibroproliferative diseases. J Clin Invest 2007, 117:524-529

3. Samarakoon R, Overstreet JM, Higgins SP, Higgins PJ: TGF- $\beta 1 \rightarrow$ $\mathrm{SMAD} / \mathrm{p} 53 / \mathrm{USF} 2 \rightarrow \mathrm{PAI}-1$ transcriptional axis in ureteral obstruction-induced renal fibrosis. Cell Tissue Res 2012, 347:117-128

4. Gruzman A, Babai G, Sasson S: Adenosine monophosphate-activated protein kinase (AMPK) as a new target for antidiabetic drugs: a review on metabolic, pharmacological and chemical considerations. Rev Diabet Stud 2009, 6:13-36

5. Mori H, Inoki K, Masutani K, Wakabayashi Y, Komai K, Nakagawa R, Guan KL, Yoshimura A: The mTOR pathway is highly activated in diabetic nephropathy and rapamycin has a strong therapeutic potential. Biochem Biophys Res Commun 2009, 384:471-475

6. Zhang BB, Zhou G, Li C: AMPK: an emerging drug target for diabetes and the metabolic syndrome. Cell Metab 2009, 9:407-416

7. Kola B, Boscaro M, Rutter GA, Grossman AB, Korbonits M: Expanding role of AMPK in endocrinology. Trends Endocrinol Metab 2006, 17:205-215

8. Luo Z, Saha AK, Xiang X, Ruderman NB: AMPK, the metabolic syndrome and cancer. Trends Pharmacol Sci 2005, 26:69-76

9. Musi N, Goodyear LJ: Targeting the AMP-activated protein kinase for the treatment of type 2 diabetes. Curr Drug Targets Immune Endocr Metabol Disord 2002, 2:119-127

10. Shackelford DB, Shaw RJ: The LKB1-AMPK pathway: metabolism and growth control in tumour suppression. Nat Rev Cancer 2009, 9: $563-575$

11. Woodard J, Joshi S, Viollet B, Hay N, Platanias LC: AMPK as a therapeutic target in renal cell carcinoma. Cancer Biol Ther 2010, 10: $1168-1177$

12. Carling D: The AMP-activated protein kinase cascade: a unifying system for energy control. Trends Biochem Sci 2004, 29:18-24

13. Cammisotto PG, Bendayan M: Adiponectin stimulates phosphorylation of AMP-activated protein kinase alpha in renal glomeruli. J Mol Histol 2008, 39:579-584

14. Eid AA, Ford BM, Block K, Kasinath BS, Gorin Y, GhoshChoudhury G, Barnes JL, Abboud HE: AMP-activated protein kinase (AMPK) negatively regulates Nox4-dependent activation of p53 and epithelial cell apoptosis in diabetes. J Biol Chem 2010, 285: 37503-37512

15. Woods A, Dickerson K, Heath R, Hong SP, Momcilovic M, Johnstone SR, Carlson M, Carling D: Ca2+/calmodulin-dependent protein kinase kinase-beta acts upstream of AMP-activated protein kinase in mammalian cells. Cell Metab 2005, 2:21-33

16. Hurley RL, Anderson KA, Franzone JM, Kemp BE, Means AR, Witters LA: TheCa2+/calmodulin-dependent protein kinase kinases are AMP-activated protein kinase kinases. J Biol Chem 2005, 280: 29060-29066

17. Hawley SA, Pan DA, Mustard KJ, Ross L, Bain J, Edelman AM, Frenguelli BG, Hardie DG: Calmodulin-dependent protein kinase kinase-beta is an alternative upstream kinase for AMP-activated protein kinase. Cell Metab 2005, 2:9-19

18. Sanderson N, Factor V, Nagy P, Kopp J, Kondalah P, Wakefield L, Roberts AB, Sporn MB, Thorgeirsson SS: Hepatic expression of mature transforming growth factor $\beta 1$ in transgenic mice results in multiple tissue lesions. Proc Natl Acad Sci U S A 1995, 92: 2572-2576

19. Inoki K, Zhu T, Guan KL: TSC2 mediates cellular energy response to control cell growth and survival. Cell 2003, 115:577-590 
20. Huang J, Manning BD: The TSC1-TSC2 complex: a molecular switchboard controlling cell growth. Biochem J 2008, 412:179-190

21. Gilbert RE, Cooper ME: The tubulointerstitium in progressive diabetic kidney disease: more than an aftermath of glomerular injury? Kidney Int 1999, 56:1627-1637

22. Iwano M, Plieth D, Danoff TM, Xue C, Okada H, Neilson EG: Evidence that fibroblasts derive from epithelium during tissue fibrosis. J Clin Invest 2002, 110:341-350

23. Rastaldi MP, Ferrario F, Giardino L, Dell'Antonio G, Grillo C, Grillo P, Strutz F, Müller GA, Colasanti G, D'Amico G: Epithelial-mesenchymal transition of tubular epithelial cells in human renal biopsies. Kidney Int 2002, 62:137-146

24. Lan HY: Tubular epithelial-myofibroblast transdifferentiation mechanisms in proximal tubule cells. Curr Opin Nephrol Hypertens 2003, 12 : $25-29$

25. Ha H, Lee HB: Reactive oxygen species and matrix remodeling in diabetic kidney. J Am Soc Nephrol 2003, 14:S246-S249

26. Schmierer B, Hill CS: TGFbeta-SMAD signal transduction: molecular specificity and functional flexibility. Nat Rev Mol Cell Biol 2007, 8: 970-982

27. Ramesh S, Qi XJ, Wildey GM, Robinson J, Molkentin J, Letterio J, Howe PH: TGF beta-mediated BIM expression and apoptosis are regulated through SMAD3-dependent expression of the MAPK phosphatase MKP2. EMBO Rep 2008, 9:990-997

28. Berrou E, Fontenay-Roupie M, Quarck R, McKenzie FR, LévyToledano S, Tobelem G, Bryckaert M: Transforming growth factor beta 1 inhibits mitogen-activated protein kinase induced by basic fibroblast growth factor in smooth muscle cells. Biochem J 1996, 316 : 167-173

29. Salt I, Celler JW, Hawley SA, Prescott A, Woods A, Carling D, Hardie DG: AMP-activated protein kinase: greater AMP dependence, and preferential nuclear localization, of complexes containing the alpha2 isoform. Biochem J 1998, 334:177-187

30. Suzuki A, Okamoto S, Lee S, Saito K, Shiuchi T, Minokoshi Y: Leptin stimulates fatty acid oxidation and peroxisome proliferator-activated receptor alpha gene expression in mouse $\mathrm{C} 2 \mathrm{C} 12$ myoblasts by changing the subcellular localization of the alpha2 form of AMPactivated protein kinase. Mol Cell Biol 2007, 27:4317-4327

31. Kasinath BS, Mariappan MM, Sataranatarajan K, Lee MJ, Feliers D: mRNA translation: unexplored territory in renal science. J Am Soc Nephrol 2006, 17:3281-3292

32. Lee MJ, Feliers D, Mariappan MM, Sataranatarajan K, Mahimainathan L, Musi N, Foretz M, Viollet B, Weinberg JM, Choudhury GG, Kasinath BS: A role for AMP-activated protein kinase in diabetes-induced renal hypertrophy. Am J Physiol Renal Physiol 2007, 292:617-627

33. Eid AA, Lee DY, Roman LJ, Khazim K, Gorin Y: Sestrin 2 and AMPK connect hyperglycemia to Nox4-dependent endothelial nitric oxide synthase uncoupling and matrix protein expression. Mol Cell Biol 2013, 33:3439-3460

34. Papadimitriou A, Peixoto EB, Silva KC, Lopes de Faria JM, Lopes de Faria JB: Increase in AMPK brought about by cocoa is renoprotective in experimental diabetes mellitus by reducing NOX4/TGF $\beta-1$ signaling. J Nutr Biochem 2014, 25:773-784
35. Habib SL, Yadav M, Tizani S, Bhandari B, Valente AJ: Tuberin inhibits production of the matrix protein fibronectin in diabetes. J Am Soc Nephrol 2012, 23:1652-1662

36. Mariappan MM, Feliers D, Mummidi S, Choudhury GG, Kasinath BS: High glucose, high insulin, and their combination rapidly induce laminin-betal synthesis by regulation of mRNA translation in renal epithelial cells. Diabetes 2007, 56:476-485

37. Block K, Eid A, Griendling KK, Lee DY, Wittrant Y, Gorin Y: Nox4 NAD(P)H oxidase mediates Src-dependent tyrosine phosphorylation of PDK-1 in response to angiotensin II: role in mesangial cell hypertrophy and fibronectin expression. J Biol Chem 2008, 283: 24061-24076

38. Lee DY, Wauquier F, Eid AA, Roman LJ, Ghosh-Choudhury G, Khazim K, Block K, Gorin Y: Nox4 NADPH oxidase mediates peroxynitrite-dependent uncoupling of endothelial nitric-oxide synthase and fibronectin expression in response to angiotensin II: role of mitochondrial reactive oxygen species. J Biol Chem 2013, 288: $28668-28686$

39. Suzuki A, Kusakai G, Shimojo Y, Chen J, Ogura T, Kobayashi M, Esumi H: Involvement of transforming growth factor-beta 1 signaling in hypoxia-induced tolerance to glucose starvation. J Biol Chem 2005, 280:31557-31563

40. Sag D, Carling D, Stout RD, Suttles J: Adenosine 5'-monophosphateactivated protein kinase promotes macrophage polarization to an antiinflammatory functional phenotype. J Immunol 2008, 181:8633-8641

41. Wang X, Pan X, Song J: AMP-activated protein kinase is required for induction of apoptosis and epithelial-to-mesenchymal transition. Cell Signal 2010, 22:1790-1797

42. Lim JY, Oh MA, Kim WH, Sohn HY, Park SI: AMP-activated protein kinase inhibits TGF- $\beta$-induced fibrogenic responses of hepatic stellate cells by targeting transcriptional coactivator p300. J Cell Physiol 2012, 227:1081-1089

43. Mishra R, Cool BL, Laderoute KR, Foretz M, Viollet B, Simonson MS: AMP-activated protein kinase inhibits transforming growth factor-beta-induced Smad3-dependent transcription and myofibroblast transdifferentiation. J Biol Chem 2008, 283:10461-10469

44. Lee JY, Chang JW, Yang WS, Kim SB, Park SK, Park JS, Lee SK: Albumin-induced epithelial-mesenchymal transition and ER stress are regulated through a common ROS-c-Src kinase-mTOR pathway: effect of imatinib mesylate. Am J Physiol Renal Physiol 2011, 300: 1214-1222

45. Ziyadeh FN, Hoffman BB, Han DC, Iglesias-De La Cruz MC, Hong SW, Isono M, Chen S, McGowan TA, Sharma K: Long-term prevention of renal insufficiency, excess matrix gene expression, and glomerular mesangial matrix expansion by treatment with monoclonal antitransforming growth factor-beta antibody in $\mathrm{db} / \mathrm{db}$ diabetic mice. Proc Natl Acad Sci U S A 2000, 97:8015-8020

46. Tesch GH, Lim AK: Recent insights into diabetic renal injury from the $\mathrm{db} / \mathrm{db}$ mouse model of type 2 diabetic nephropathy. Am J Physiol Renal Physiol 2011, 300:F301-F310

47. Shibuya K, Kanasaki K, Isono M, Sato H, Omata M, Sugimoto T, Araki S, Isshiki K, Kashiwagi A, Haneda M, Koya D: N-acetyl-serylaspartyl-lysyl-proline prevents renal insufficiency and mesangial matrix expansion in diabetic $\mathrm{db} / \mathrm{db}$ mice. Diabetes 2005, 54:838-845 